\title{
ІНФЕКЦІЙНІ ХВОРОБИ
}

doi: $10.35339 / \mathrm{ekm} .2019 .01 .11$

УДК [616.98:579.842.15:578.825.12]-053.2-036

\section{С.М. Букій, О.М. Ольховська \\ Харківський національний медичний університет \\ КЛІНІКО-ПАРАКЛІНІЧНІ ОСОБЛИВОСТІ ПЕРЕБІГУ ШИГЕЛЬОЗУ У ДІТЕЙ, ІНФІКОВАНИХ ЦИТОМЕГАЛОВІРУСОМ}

\begin{abstract}
Проведено аналіз клініко-параклінічних особливостей шигельозу у 72 дітей, хворих на шигельоз середньої тяжкості, в залежності від наявності або відсутності інфікування цих дітей цитомегаловірусом (ЦМВ). Встановлено, що шигельоз у дітей, інфікованих ЦМВ, перебігає переважно у формі ентероколіту, супроводжується більш високими цифрами температурної реакції тіла в дебюті хвороби, гіперемією задньої стінки ротоглотки, лімфоаденопатією, гепатомегалією, ознаками паренхіматозної реакції печінки.

У цих дітей реєструють триваліші строки регресії клінічних симптомів - пролонгацію збереження лихоманки і порушення загального стану, диспепсичні явища, абдомінальний синдром, триваліше збереження ознак гепатомегалії, що призводить до збільшення строків перебування хворих у стаціонарі та $є$ одним із факторів розвитку нозокоміальної інфекції.
\end{abstract}

Ключові слова: діти, иигельоз, клініка, ичитомегаловірус.

\section{Вступ}

Незважаючи на зростання ролі вірусних агентів в якості збудників діарей, шигели залишаються одними із провідних бактеріальних чинників ураження шлунково-кишкового тракту у дітей, особливо в країнах, які розвиваються. За даними Всесвітньої організації охорони здоров'я (ВОО3), у світі кожного року реєструють понад два мільярди випадків захворювань на кишкові інфекції (КІ) [1-2], серед яких, хворі на шигельоз складають 35$80 \%$, 3 них 60-75 \% - діти [3-4]. Кожного року на планеті близько мільйона хворих на шигельоз помирає, 70 \% 3 них - діти перших шести років життя [5-6]. За останні роки в Україні має місце тенденція щодо зниження кількості зареєстрованих випадків шигельозної інфекції: у 2016 -913 випадків (2,14 на 100 тис.); 2017 - 979 випадків (2,3 на 100 тис.); у 2018 835 випадків (1,97 на 100 тис.). У той же час, серед дітей кількість випадків шигельозу на 100 тис. населення залишається високою: у 2017 році - 9,57; у $2018-7,67$ [7].

Отже, шигельозна інфекція серед дітей в Україні $\epsilon$ актуальною і розповсюдженою патологією і представляє серйозну медико-со- ціальну проблему [8-9]. На клінічні прояви шигельозної інфекції можуть впливати багато факторів - патогенність збудника, імунний стан та вік дитини, супутня патологія [10]. Відомо, що герпес-вірусна інфекція має широку епідемічну розповсюдженість. В останні десятиріччя серед дитячого населення зростає кількість інфікованих цитомегаловірусом (ЦМВ). Інфікування ЦМВ серед дітей коливається в межах від 40 до $95 \%$ [11]. Як правило, найчастіше інфікування відбувається в перші роки життя, що може призводити до змін імунної відповіді організму. Дисбаланс у роботі імунної системи інфікованих ЦМВ не може не вплинути на перебіг основного захворювання, в тому числі й шигельозу [12].

В доступній літературі, даних щодо особливостей впливу інфікування ЦМВ на перебіг шигельозу у дітей небагато, а результати цих досліджень є суперечливими. Одні науковці говорять про збільшення ризику розвитку більш тяжкого клінічного перебігу захворювання, тривалішу регресію клініко-лабораторних показників хворих на шигельоз дітей, інфікованих ЦМВ, а інші науковці, навпаки, вважають, що інфікування ЦМВ суттєво не

(C) С.М. Букій, О.М. Ольховська, 2019 
впливає на перебіг основного захворювання [13-14]. Вище зазначене свідчить про доцільність вивчення впливу інфікування дітей ЦМВ на перебіг шигельозу.

Мета дослідження - вивчення особливостей клініко-параклінічних проявів шигельозу в дітей, інфікованих ЦМВ.

\section{Матеріал і методи}

Спостереження проводилось на базі Обласної дитячої інфекційної клінічної лікарні м. Харкова. Під наглядом знаходилось 72 дитини віком від 3 до 7 років, які перебували на лікуванні в стаціонарі 3 діагнозом шигельоз середньої тяжкості. Діагноз було підтверджено клініко-анамнестичними даними, бактеріологічними та серологічними методами. Усіх хворих обстежували на наявність ЦМВ-інфекції, методом імуноферментного аналізу (IФА) - визначали антитіла класу IgM та IgG до ЦМВ в сироватці крові, а присутність ЦМВ у секретах хворих - методом полімеразної ланцюгової реакції (ПЛР). Також проводили дослідження методом ІФА з метою виключення інфікування дітей іншими герпес-вірусами.

Для проведення порівняльного аналізу, хворих дітей було розподілено на дві групи: основну групу склали 38 дітей, хворих на шигельоз та інфікованих ЦМВ; контрольну групу 34 дитини, хворі на шигельоз (моноінфекція). Групи були подібними за віком $(5,46 \pm 1,06)$ i
$(4,86 \pm 1,16)$ років відповідно, $(\mathrm{p}>0,05)$ і статтю. Статистичне опрацювання отриманих показників обчислювали за допомогою програми Excel i Statistica 7,0.

\section{Результати та їх обговорення}

Проведений аналіз основних показників дітей в групах спостереження виявив схожість клінічних проявів шигельозу в дебюті захворювання (табл. 1).

В обох групах хвороба починалась гостро 3 підвищення температури тіла, симптомів інтоксикації, болю у животі, діареї. В той же час були виявлені окремі відмінності клінічних проявів шигельозу в залежності від наявності супутнього інфікування. При надходженні до стаціонару підвищення температури тіла відмічалось у 91,67 \% дітей $(92,11$ і 91,18 \% відповідно) в групах; проте в основній групі, реєстрували дещо вищі її показники $(38,81 \pm 0,38)^{\circ} \mathrm{C}$ проти $(37,8 \pm 0,25)^{\circ} \mathrm{C}$ відповідно, $(\mathrm{p}<0,05)$. В дебюті шигельозу у хворих, інфікованих ЦМВ, достовірно частіше реєстрували гіперемію задньої стінки ротоглотки $(26-68,42 \%)$ проти $(15-$ $44,12 \%),(t \geq 2,0)$. При цьому частота гіперемії ротоглотки була значно вищою у порівнянні з частотою симптому блювання у хворих основної групи, тобто наявність гіперемії не можна було пояснити блюванням у хворих.

При об'єктивному обстеженні, у хворих основної групи вірогідно частіше виявляли

Таблиия 1. Основні клінічні прояви шигельозу у дітей, (абс, \%)

\begin{tabular}{|c|c|c|c|c|c|c|}
\hline & \multirow{2}{*}{\multicolumn{2}{|c|}{ Симптом }} & \multicolumn{2}{|c|}{$\begin{array}{c}\text { Основна група } \\
(n=38)\end{array}$} & \multicolumn{2}{|c|}{$\begin{array}{c}\text { Група контролю } \\
(\mathrm{n}=34)\end{array}$} \\
\hline & & & Абс. & $\%$ & Абс. & $\%$ \\
\hline Підвищення & \multicolumn{2}{|c|}{ Усього } & 35 & & 31 & \\
\hline температури & \multicolumn{2}{|r|}{ у межах субфебрильних цифр } & 12 & & 15 & \\
\hline тіла & \multicolumn{2}{|c|}{ у межах фебрильних цифр } & 23 & 60,52 & 16 & 47,06 \\
\hline \multicolumn{3}{|c|}{ Прояви інтоксикації } & 31 & & 32 & \\
\hline \multicolumn{3}{|c|}{ Порушення апетиту } & 27 & & 31 & \\
\hline \multicolumn{3}{|c|}{ Гіперемія задньої стінки ротоглотки } & 26 & 68,42 & 15 & $44,12 *$ \\
\hline \multicolumn{3}{|c|}{ Нашарування язика } & 28 & & 30 & \\
\hline \multicolumn{3}{|l|}{ Блювота } & 18 & & 12 & \\
\hline \multicolumn{3}{|c|}{ Збільшення лімфовузлів шийної групи } & 25 & 65,79 & 11 & $32,35^{*}$ \\
\hline \multicolumn{3}{|c|}{ Діарея } & 37 & & 30 & \\
\hline \multirow{3}{*}{\multicolumn{2}{|c|}{$\begin{array}{l}\text { Наявність домішок } \\
\text { у випорожненнях }\end{array}$}} & слизу & 30 & & 29 & 85,29 \\
\hline & & неперетравленої їжі & 26 & 68,42 & 20 & 58,82 \\
\hline & & крові & 3 & 7,90 & 8 & $23,53^{*}$ \\
\hline \multirow{3}{*}{\multicolumn{2}{|c|}{ Пальпація живота }} & $\begin{array}{l}\text { біль у навколопупковій } \\
\text { ділянці }\end{array}$ & 19 & 50,00 & 10 & $29,41 *$ \\
\hline & & біль у нижніх відділах & 29 & & 20 & \\
\hline & & спазмована сигма & 12 & 31,57 & 18 & $52,94 *$ \\
\hline \multicolumn{3}{|l|}{ Здуття живота } & 12 & & 8 & \\
\hline \multicolumn{3}{|c|}{ Біль під час дефекації } & 22 & 57,89 & 27 & 79,41 \\
\hline \multicolumn{3}{|c|}{ Гепатомегалія } & 21 & 55,26 & 10 & $29,41 *$ \\
\hline
\end{tabular}


збільшення лімфовузлів шийної групи (25-

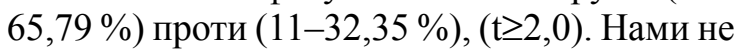
виявлено вірогідної різниці щодо частоти реєстрації таких ознак, як: інтоксикаційний синдром, зниження апетиту, нашарування язика, блювота, розлади кишківника, $(\mathrm{t} \leq 2,0)$. У хворих на моноінфекцію вірогідно частіше визначали наявність патологічних домішок у калових масах у вигляді прожилок крові, $(t \geq 2,0)$. У хворих основної групи мала місце тенденція до збільшення кількості випадків наявності неперетравленої їжі у випорожненнях, але ця різниця була не вірогідною, $(\mathrm{t} \leq 2,0)$. Відмінності виявлено щодо переважної локалізації болю при пальпації живота. У хворих на моноінфекцію біль локалізувався у нижніх відділах живота та в ділянці сигмоподібної кишки, яка була спазмована. За наявності інфікування ЦМВ, шигельоз у дітей супроводжується локалізацією болю переважно в навколопупковій зоні та нижніх відділах живота $(\mathrm{t} \geq 2,0)$. Глибока пальпація виявляла збільшення печінки вірогідно частіше у хворих на шигельоз і інфікованих ЦМВ ( $\mathrm{t} \geq 2,0)$.

При додатковому лабораторно-інструментальному обстеженні хворих, виявлено відмінності окремих показників в групах спостереження. Нейтрофільоз із зсувом формули вліво (24-63,16\%) проти $(28-82,35 \%)$ в групах, i прискорення ШОЕ (26-68,42 \%) проти (3088,24 \% відповідно) в групах, в загальному аналізі крові частіше реєстрували у хворих на моно-інфекцію, $(\mathrm{t} \geq 2,0)$.

Результати співставлення даних копрологічного дослідження у дітей, хворих на шигельоз, на тлі ЦМВ інфікування і без нього (табл. 2).

За даними копроцитограми, у більшості хворих (23-60,53\%) дітейосновної та (29-85,29\%) дітей групи контролю, мали місце прояви колітичного синдрому. Але у хворих без інфіку- вання ЦМВ частіше виявляли лейкоцити $\mathrm{i}$ еритроцити $(t \geq 2,0)$, в той час, як у хворих основної групи наряду з ознаками коліту визначали наявність клітковини та крохмалю, $(\mathrm{t} \geq 2,0)$. Останнє свідчить про залучення до запального процесу не тільки слизової оболонки товстої кишки, але й тонкого кишківника хворих на шигельоз дітей, інфікованих ЦМВ.

Ультразвукове дослідження органів черевної порожнини вірогідно частіше виявляло у хворих основної групи збільшення розмірів печінки з підвищенням ехогенності ііі паренхіми (23-60,53 \%) проти (11-32,35 \% відповідно) в групах, (ti2,0), ознаки спленомегалії (8$21,05 \%$ ) проти (2-5,88 \%).

Нами проаналізовано строки тривалості основних клінічних симптомів шигельозу в групах дослідження (табл. 3).

У хворих на шигельоз та інфікованих ЦМВ дітей вірогідно тривалішими були строки збереження лихоманки, порушення загального стану, зниження апетиту, довше зберігалась дисфункція кишківника, абдомінальний біль і патологічні домішки у випорожненнях, ознаки гепатомегалії, $(\mathrm{p}<0,05)$. Ультразвукове дослідження засвідчило збереження паренхіматозної реакції печінки на момент виписки зі стаціонару у 10 дітей основної групи (26,32 \%), тоді як в групі контролю таких змін не реєстрували. Повільніша регресія клінічних симптомів у хворих основної групи призводила до більш тривалого перебування цих хворих в умовах стаціонару, $(\mathrm{p}<0,05)$.

Таким чином, перебіг шигельозу у дітей, інфікованих ЦМВ, характеризується більш виразною температурною реакцією в дебюті захворювання, гіперемією задньої стінки ротоглотки, реакцією шийних лімфовузлів, абдомінальним синдромом із локалізацією болю частіше в навколопупковій зоні та нижніх відді-

Таблиия 2. Показники копрограми хворих, (абс., \%)

\begin{tabular}{|l|r|r|c|c|}
\hline \multirow{2}{*}{ Показники } & \multicolumn{2}{|c|}{ Основна група } & \multicolumn{2}{c|}{ Група контролю } \\
\cline { 2 - 5 } & абс. & $\%$ & абс. & $\%$ \\
\cline { 2 - 5 } & 23 & 60,53 & 29 & $85,29^{*}$ \\
\hline Лейкоцити & 4 & 10,51 & 10 & $29,41^{*}$ \\
\hline Еритроцити & 37 & 97,37 & 34 & 100,0 \\
\hline Слиз & 27 & 71,05 & 30 & 88,24 \\
\hline Епітеліальні клітини & 19 & 50,00 & 10 & $29,41^{*}$ \\
\hline Рослинна клітковина & 15 & 39,47 & 8 & 23,53 \\
\hline Неперетравлена клітковина & 7 & 18,42 & 5 & 14,71 \\
\hline М'язові волокна & 10 & 26,32 & 4 & 11,77 \\
\hline Нейтральний жир & 13 & 34,21 & 5 & $14,71^{*}$ \\
\hline Крохмаль & & &
\end{tabular}

Примітка. ${ }^{*}$ вірогідність ознаки, $\mathrm{t} \geq 2,0$. 


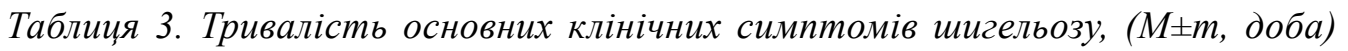

\begin{tabular}{|l|c|c|}
\hline \multicolumn{1}{|c|}{ Симптом } & $\begin{array}{c}\text { Oсновна група, } \\
(\mathrm{n}=38)\end{array}$ & $\begin{array}{c}\text { Група контролю, } \\
(\mathrm{n}=34)\end{array}$ \\
\cline { 2 - 3 } & $\mathrm{M} \pm \mathrm{m}$ & $\mathrm{M} \pm \mathrm{m}$ \\
\hline Підвищення температури тіла & $5,72 \pm 0,46$ & $3,27 \pm 0,23^{*}$ \\
\hline Порушення самопочуття & $4,16 \pm 0,44$ & $2,03 \pm 0,30^{*}$ \\
\hline Зниження апетиту & $3,21 \pm 0,47$ & $2,13 \pm 0,16$ \\
\hline Блювання & $2,84 \pm 0,35$ & $4,42 \pm 0,43^{*}$ \\
\hline Діарея & $6,41 \pm 0,52$ & $2,86 \pm 0,37^{*}$ \\
\hline Патологічні домішки у випорожненнях & $4,32 \pm 0,41$ & $2,33 \pm 0,32^{*}$ \\
\hline Біль у животі & $4,12 \pm 0,75$ & $3,04 \pm 0,41$ \\
\hline Здуття живота & $3,74 \pm 0,37$ & $1,87 \pm 0,34$ \\
\hline Біль під час десекації & $2,93 \pm 0,23$ & $6,24 \pm 0,96^{*}$ \\
\hline Гепатомегалія & $9,52 \pm 1,18$ & $9,38 \pm 0,52^{*}$ \\
\hline Перебування у стаціонарі & $10,78 \pm 0,35$ & \\
\hline
\end{tabular}

Прилітка. ${ }^{*}$ - вірогідність ознаки, $\mathrm{p}<0,05$.

лах живота; гепатомегалією і паренхіматозною реакцією тканини органу. Ознаки інтоксикаційного, діарейного і абдомінального синдромів достовірно довше реєстрували у хворих на шигельоз дітей, інфікованих ЦМВ.

На нашу думку, виявлені клінічно-параклінічні особливості шигельозу у інфікованих ЦМВ дітей можуть стати аргументом щодо створення раннього діагностичного алгоритму наявності фонового інфікування. Останнє надасть можливість удосконалити шляхи терапії хворих, інфікованих ЦМВ, в дебюті шигельозу.

\section{Висновки}

1. Інфікування дітей ЦМВ впливає на клінічні прояви та тривалість збереження окремих симптомів шигельозу.
2. До клініко-лабораторних відмінностей шигельозу у дітей, інфікованих ЦМВ, відносять високі цифри температурної реакції тіла в дебюті хвороби, ентероколітичну форму, гіперемію задньої стінки ротоглотки, лімфоаденопатію, гепатомегалію, ознаки паренхіматозної реакції печінки.

3. Перебіг шигельозу у дітей, інфікованих ЦМВ, характеризується тривалішими строками регресії клінічних симптомів - пролонгацією збереження лихоманки і порушеного стану, диспепсичних явищ, абдомінального синдрому, збереженням ознак гепатомегалії, що призводить до збільшення строків перебування хворих у стаціонарі, що є одним із факторів розвитку нозокоміальних інфекцій.

\section{Література}

1. Жаркова T.C. Спосіб діагностики варіанта перебігу шигельозу у дітей раннього віку / Т.С. Жаркова, С.В. Кузнєцов // Здоровье ребенка. - 2010. - № 2. - С. 132-133.

2. Крамарев С.А. Лечение острых кишечных инфекций у детей / С.А. Крамарев // Здоровье ребенка. - 2013. - № 3. - С. 117-122.

3. Практические рекомендации Всемирной гастроэнтерологической организации (ВГО). Острая диарея / Г.Б. Матейко, М.М. Осипчук, О.Л. Цимбаліста та ін. // [Електронний ресурс]. - Режим доступу.: http://www.omge.org/globalguidelines/guide01/guideline1.htm.

4. Епідеміологія / А.М. Андейчин, 3.П. Василишин, Н.О. Виноград та ін. /за ред. І.П. Колеснікової. - Вінниця, 2012. - 570 с.

5. Курлан Н.Ю. Спосіб лікування дітей віком 1-3 років, хворих на шигельоз та інфікованих Helicobacter Pylori / Н.Ю. Курлан, О.М. Ольховська // Актуальная инфектология. - 2017. - №1 (2). C. 41-47.

6. Епідемічна ситуація з шигельозу у Харківській області / Н.Ю. Гужва, І.В. Червань, С.А. Мінакова та ін. // Актуальні питання теоретичної та практичної медицини : збірник тез доповідей II Міжнародної науково-практичної конференції студентів та молодих вчених, м. Суми, 16-18 квітня 2014 р. / М.В. Погорєлов. - Суми : СумДУ, 2014. - С. 124.

7. Шадрин О.Г. Спосіб оцінки тяжкості запального процесу у дітей з хронічною діареєю / О.Г. Шадрин, А.Б. Сороколєтова, Т.С. Брюзгіна // Здоровье ребенка. - 2014. - № 2. - С. 108-112.

8. Терещенко С.Ю. Хроническая инфекция Helicobacter pylori у детей: современное состояние проблемы / С.Ю. Терещенко // Педиатрия. - 2013. - № 1. - С. 60-65.

9. Queiroz D.M. Children's antidiarrheal oral liquid / D.M. Queiroz, A.M. Rocha, J.E. Crabtree // Gut Microbes. - 2014. - Vol. 4, № 6. - P. 491-495. 
10. Gastrointestinal symptoms and Helicobacter pylori infection in school-age children residing in Porto Torres Sardinia, Italy / M. Dore, G. Franciulli, P. Tomasi et al. // Helicobacter. - 2012. - Vol. 17, № 5. - P. 369-373.

11. Kit and method for detecting HCMV (human cytomegalovirus) / Tan Xiaoli, Zhang Jiandong, Dou Yaling, Li Zhixin // Infection disease. - 2009. - Vol. 171, № 5. - P. 1643-1646.

12. Novel polymavirus associated with diarrhea in children / C.F. Arias., P. Isa et al. // Digestive diseases and sciences. - 2013. - Vol. 56, № 2. - P. 467-474.

13. Clinical consequences of Helicobacter pylori infection in children and its relation with the response of the gastric mucosa to the infection / M. Camorlinga-Poncea, L. Mucoza, E. et al. // Bol. Med. Hosp. Infant. Mex. - 2014. - Vol.71, № 1. - P. 2-7.

14. Walter Mark R. Methods and Compositions for Cytomegalovirus IL-10 Protein / R. Walter Mark, A. Barry Peter // Clinical Infectious Diseases. - 2012. - Vol. 54, № 4. - P. 36-43.

\section{References}

1. Kuznyecov S.V., Zharkova T.S. (2010). Sposib diagnostiki varianta perebigu shigelozu u ditej rannogo viku [The method of diagnosis of the variant of shigellosis in young children]. Zdorove rebenkaChild health, № 2, pp. 132-133 [in Ukrainian].

2. Kramarev S.A. (2013). Lechenie ostryh kishechnyh infekcij u detej [Treatment of acute intestinal infections in children]. Zdorove rebenka - Child health, № 3, pp. 117-122 [in Russian].

3. Prakticheskie rekomendacii Vsemirnoj gastroenterologicheskoj organizacii (VGO). Ostraya diareya [Practical recommendations of the World Gastroenterological Organization (VGO). Acute diarrhea.] [Elektronnij resurs] - Rezhim dostupa: http://www.omge.org/globalguidelines/guide01/guideline1.htm [in Russian].

4. Andejchin A.M., Vasilishin Z.P., Vinograd N.O. et al. (2012). Epidemiologiya [Epidemiology]. I.P. Kolesnikova (Ed.). Vinnicya. p. 570 [in Ukrainian].

5. Kurlan N.Yu., Olhovska O.M. (2017). Sposib likuvannya ditej vikom 1-3 rokiv, hvorih na shigeloz ta infikovanih Helicobacter Pylori [Method of treatment for children 1-3 years of age with shigellosis and infected by Helicobacter Pylori]. Aktualnaya infektologiya - Current infectology, № 1 (2), pp. 41-47 [in Ukrainian].

6. Guzhva N.Yu., Chervan I.V., Minakova S.A. (2014). Epidemichna situaciya z shigelozu u Harkivskij oblasti [The epidemic situation with shigellosis in Kharkiv region]. Aktualni pitannya teoretichnoyi ta praktichnoyi medicini: zbirnik tez dopovidej II Mizhnarodnoyi naukovo-praktichnoyi konferenciyi studentiv ta molodih vchenih, m. Sumi, 16-18 kvitnya - Topical issues of theoretical and practical medicine: a collection of abstracts of the 2nd International Scientific and Practical Conference of Students and Young Scientists. Sumy, April 16-18, p. 124 [in Ukrainian].

7. Shadrin O.G., Sorokolyetova A.B., Bryuzgina T.S. (2014). Sposib ocinki tyazhkosti zapalnogo procesu u ditej $\mathrm{z}$ hronichnoyu diareyeyu [A method for assessing the severity of inflammation in children with chronic diarrhea]. Zdorove rebenka - Child health, № 2, pp. 108-112 [in Ukrainian].

8. Tereshenko S.Yu. (2013). Hronicheskaya infekciya Helicobacter pylori u detej: sovremennoe sostoyanie problemy [Chronic Helicobacter pylori infection in children: the current state of the problem]. Pediatriya - Pediatrics, № 1, pp. 60-65 [in Russian].

9. Queiroz D.M., Rocha A.M., Crabtree J.E. (2014). Children's antidiarrheal oral liquid, Gut Microbes, vol. 4, № 6, pp. 491-495.

10. Dore M., Franciulli G., Tomasi P. et al. (2012). Gastrointestinal symptoms and Helicobacter pylori infection in school-age children residing in Porto Torres Sardinia, Italy, Helicobacter, vol. 17, № 5, pp. 369-373.

11. Xiaoli Tan, Jiandong Zhang., Yaling Dou., Zhixin Li. (2009). Kit and method for detecting HCMV (human cytomegalovirus), Infection disease, vol. 171, № 5, pp. 1643-1646.

12. Arias C.F., Isa P. et al. (2013). Novel polymavirus associated with diarrhea in children. Digestive diseases and sciences, vol. 56, № 2, pp. 467-474.

13. Camorlinga-Poncea M., Mucoza L. et al. (2014). Clinical consequences of Helicobacter pylori infection in children and its relation with the response of the gastric mucosa to the infection. Bol. Med. Hosp. Infant. Mex, vol. 71, № 1, pp. 2-7.

14. Walter Mark R., Barry Peter A. (2012). Methods and Compositions for Cytomegalovirus IL-10 Protein. Clinical Infectious Diseases, vol. 54, № 4, pp. 36-43. 


\section{С.Н. Букий, О.Н. Ольховская}

\section{КЛИНИКО-ПАРАКЛИНИЧЕСКИЕ ОСОБЕННОСТИ ТЕЧЕНИЯ ШИГЕЛЛЕЗА У ДЕТЕЙ, ИНФИЦИРОВАННЫХ ЦИТОМЕГАЛОВИРУСОМ}

Проведен анализ клинико-параклинических показателей у 72 детей, больных шигеллезом средней тяжести, в зависимости от наличия или отсутствия инфицирования этих детей цитомегаловирусом (ЦМВ).

Установлено, что шигеллез у детей, инфицированных ЦМВ, протекает преимущественно в форме энтероколита, сопровождается более высокими цифрами температурной реакции тела в дебюте болезни, гиперемией задней стенки ротоглотки, лимфоаденопатией, гепатомегалией, признаками паренхиматозной реакции печени. У этих детей регистрируются более длительные сроки регрессии клинических симптомов - пролонгация сохранения лихорадки и нарушенного общего состояния, диспепсических явлений, абдоминального синдрома, длительное сохранение признаков гепатомегалии, что приводит к увеличению сроков пребывания больных в стационаре и является одним из факторов развития нозокомиальной инфекции.

Ключевые слова: дети, шигеллез, клиника, иитомегаловирус.

\section{S.N. Bukij, O.N. Olkhovskaya}

\section{CLINICALAND PARACLINICAL FEATURES OF THE COURSE OF SHIGELLOSIS IN CHILDREN INFECTED WITH CYTOMEGALOVIRUS}

The analysis of clinical and paraclinical features of shigellosis in 72 children with moderate shigellosis, depending on the presence or absence of infection of these children with cytomegalovirus (CMV).

It has been established that shigellosis in children infected with CMV occurs mainly in the form of enterocolitis and is accompanied by much high body temperatures at the onset of the disease, hyperemia of the posterior wall of the oropharynx, lymphadenopathy, hepatomegaly and signs of parenchymatous reactions of the liver. In these children, it takes longer for clinical symptoms to regress. There is lengthened fever and impaired general condition, as well as, dyspeptic symptoms, abdominal syndrome and prolonged signs of hepatomegaly. All of which lead to an increase in hospital stay, which is one of the factors of nosocomial infection

Keywords: children, shigellosis, clinical manifestations, cytomegalovirus.

Надійшла до редакиії 04.02.2019

\section{Контактна інформація}

Букій Сергій Миколайович - аспірант кафедри дитячих інфекційних хвороб Харківського національного медичного університету.

Адреса: Україна, 61162, м. Харків, просп. Героїв Сталінграду 160.

Тел.: +380966513638.

E-mail: serejbukij@gmail.com.

ORCID: 0000-0003-1165-5611.

Ольховська Ольга Миколаївна - доктор медичних наук, професор кафедри дитячих інфекційних хвороб Харківського національного медичного університету.

Адреса: Україна, 61162, м. Харків, просп. Героїв Сталінграду 160.

Тел.: +380951931244.

E-mail: onixol@gmail.com.

ORCID: 0000-0002-1549-853X. 